\title{
耐熱性高分子材料の加熱による 気体放出特性と構造変化*
}

\author{
中山 喜明** . 福田 伸**. 山科 俊郎**
}

（受付1989年11月 30 日，掲載決定1990年 1 月 6 日）

\begin{abstract}
Outgassing and Structural Change of Heat-Resistant
Polymer Materials during and after Heat Treatment*

Yoshiaki NAKAYAMA**, Shin FUKUDA** and Toshiro YAMASHINA**

(Department of Nuclear Engineering, Faculty of Engineering, Hokkaido University, Sapporo)
\end{abstract}

(Received November 30, 1989, Accepted January 6, 1990)

\section{1. はじめに}

ポリイミド樹脂は現在数多くある高分子材料の中で最 も耐熱性に優れ，また高弾性，電気絶縁性等の特性や軽 量で加工性の良いことなどから，各種工業材料を始め， 近年ではガスケットや絶縁シール等の真空材料 ${ }^{1,2)}$ や, 人工衛星の構造材 ${ }^{3)}$ への適用が進められている. しか し，一般的に有機材料は金属材料に比べ熱に対し不安定 で，真空中での気体放出量が多く，また熱分解などの不 可逆的な反応の進行により各種特性が劣化しやすいた め4), 超高真空を得るための高温ベーキングや宇宙空間 での太陽による熱輻射などの高温熱環境下での使用可能 範囲を明確にする必要がある。そこで本研究では, 3 種 類のポリイミド樹脂を真空中で加熱し, その時の気体放 出特性を調べ, また劣化の原因である熱分解による重量 変化や構造変化について調べたので報告する。

\section{2. 実験}

Fig. 1 に本実験で使用した 3 種類のポリイミド樹脂, Kapton(東レ, Du Pont), Upilex S, Upilex R（宇部興産） の化学構造式とガラス転移温度 $(\mathrm{Tg})^{5)}$ を示す。ここで, ガラス転移温度は, 融点と同様に分子間力が大きくなる 程, また結合が剛直なもの程高くなる傾向があり, 今回 の実験では耐熱性の指標となると考えられる。.また, 加

* 平成元年10月26日第30回真空に関する連合講演会で発表 $(20 \mathrm{Bp}-7)$

** 北海道大学工学部原子工学科 (札幌市北区北13西 8)

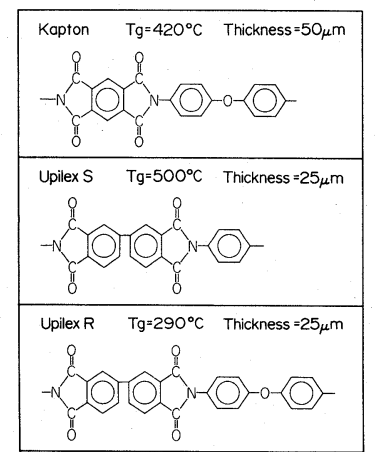

Fig. 1 Structural Formula and Glass Transition Temperatures of Polyimides.

熱による気体放出特性の測定では，これらの試料を 12 $\mathrm{mm}$ 四方の大ささに切り出し, エタノールで30分間の超 音波洗浄を行った後, 昇温脱離分析装置6)にセットし, $170^{\circ} \mathrm{C}, 20$ 時間の装置予備加熱の後試料を加熱し, その 時の放出気体を QMS により測定した。そして, 得られ た質量スペクトルの $\mathrm{m} / \mathrm{e}=2 \sim 46$ のピークについて気体 の定量分析》を行った. また, 加熱後の試料の重量変化 と結合状態の変化は, マイクロ天秤及び FT-IRにより 測定した.

\section{3. 結 果}

\section{1 気体放出特性}

Fig. 2 に Kapton $530^{\circ} \mathrm{C} て ゙$ 加熱したときの質量スペ 


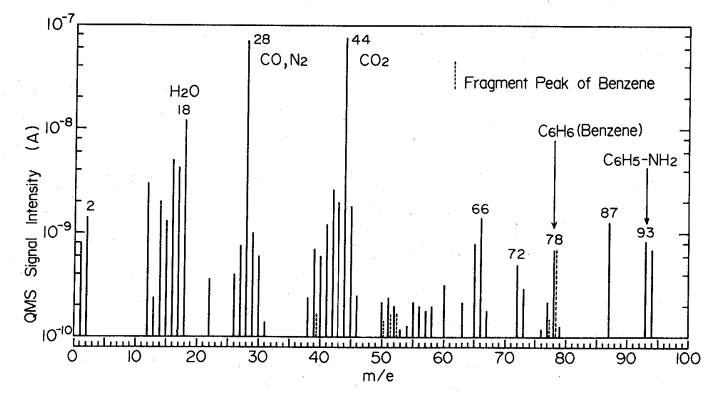

Fig. 2 Mass Spectrum of Gases Desorbed Thermally from Kapton at $530^{\circ} \mathrm{C}$.
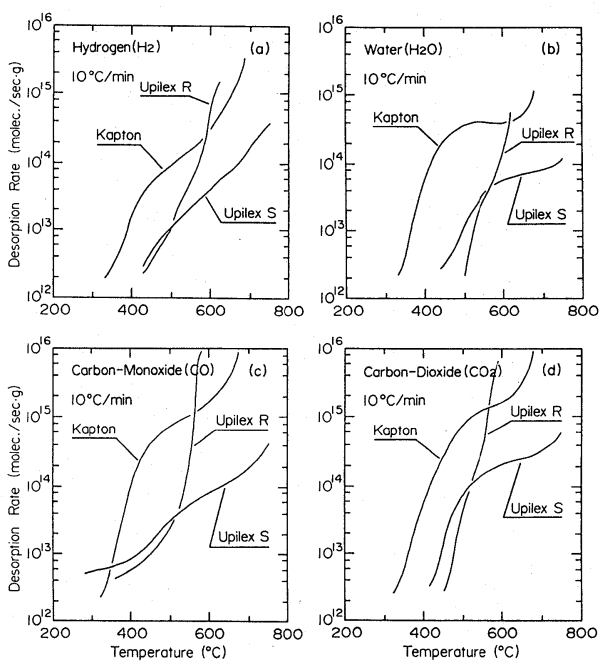

Fig. 3 Thermal Desorption Spectra of (a) $\mathrm{H}_{2}$, (b) $\mathrm{H}_{2} \mathrm{O}$, (c) $\mathrm{CO}$ and (d) $\mathrm{CO}_{2}$ from Kapton, Upilex $\mathrm{S}$ and Upilex R.

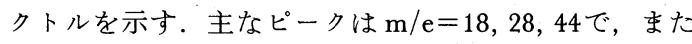
かなりの炭化水素, むしくは有機化合物のフラグメント に相当するピークが質量数100付近まで比較的大きな信 号強度で現れている．その中で質量数78のピークはベン ゼンに相当すると考えられ， $\mathrm{m} / \mathrm{e}=50,51,52,77$ のフ グメントピークは, ベンゼンのパターン係数 ${ }^{8)}$ とくー 致している.このことから, 熱分解により $\mathrm{CO}, \mathrm{CO}_{2}$ 等 の低分子量の気体だけでなく，モノマーやベンゼンの様 な高分子量の気体も同時に脱離していることが考えられ る.

次に，各試料を室温から $700^{\circ} \mathrm{C}$ 付近まで, $10^{\circ} \mathrm{C} / \mathrm{min}$ で 加熱した時の放出気体の脱離スペクトルをFig. 3 に示 す. 主な気体は, ぞの試料でも水素, 一酸化炭素, 二酸 化炭素, 水で, その中でも一酸化炭素, 二酸化炭素の放 出速度は温度の上昇と共に顕著に増加している。また，

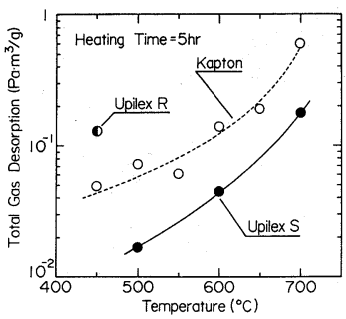

Fig. 4 Amount of Gases Desorbed Thermally during Isothermal Heating for $5 \mathrm{hr}$.

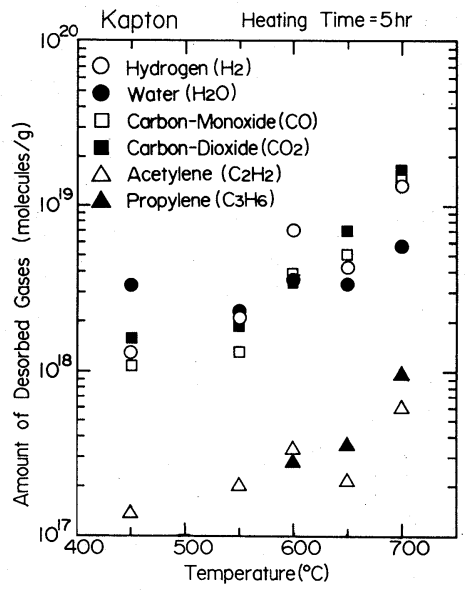

Fig. 5 Amount of Gases Desorbed Thermally during Isothermal Heating for $5 \mathrm{hr}$.

各々の試料の気体放出は, Kapton では $300^{\circ} \mathrm{C} か ら$ 増加 し, $500^{\circ} \mathrm{C}$ 付近で一旦緩やかになった後, $600^{\circ} \mathrm{C}$ から再

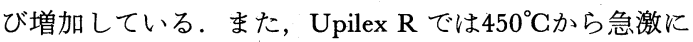
放出速度が増加し, $570^{\circ} \mathrm{C} て ゙$ Kaptonの放出速度を上回 っている. 一方, Upilex S は他の 2 つに比べ熱的に最も 安定で, $700^{\circ} \mathrm{C}$ 以上でも増加の傾向は比較的緩やかであ ることが分かる。

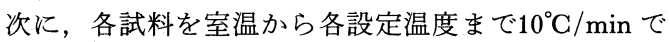
昇温し，その温度で 5 時間の加熱を行った時の気体放出 量をFig. 4 に示す. 全気体放出量はKaptonの場合 $450^{\circ} \mathrm{C}$ から $700^{\circ} \mathrm{C}$ の加熱で $5 \times 10^{-2} \sim 6 \times 10^{-1}\left(\mathrm{~Pa} \cdot \mathrm{m}^{3} / \mathrm{g}\right)$ まで増加し，またUpilex R では $450^{\circ} \mathrm{C} て ゙ 1.3 \times 10^{-1}(\mathrm{~Pa}$. $\mathrm{m} 3 / \mathrm{g}$ ) と Kaptonの約 2 倍となっており，逆に Upilex

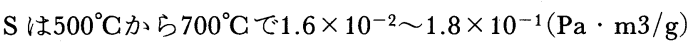
と Kaptonの1/3から1/4となっている.このことから， 気体放出量からみた各試料の加熱に対する安定性は, Upilex S, Kapton, Upilex R，という順番になり，ガラ ス転移温度から予想される結果と一致している.

また, Kaptonについて, 個々の気体の放出量を Fig. 


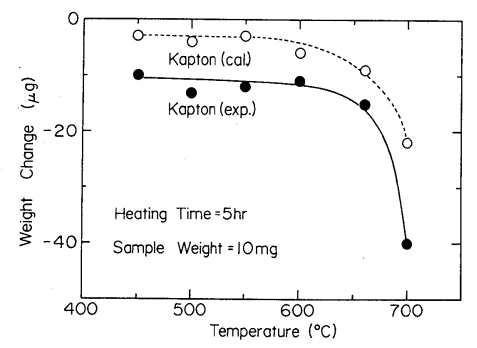

Fig. 6 Weight Change of Kapton after Isothermal Heating for $5 \mathrm{hr}$.

5 亿示す。主な放出気体である水素, 一酸化炭素, 二酸 化炭素の脱離量は $450^{\circ} \mathrm{C}$ から $700^{\circ} \mathrm{C}$ 加熱温度で，10 $10^{18}$ $10^{19}$ (分子/g）までほぼ同様に増加して招り, 炭化水素 系のアセチレンやプロピレンはそれらより約 1 桁ほど少 なくなっている.この中で, 水の脱離量は加熱温度の上 昇に対し余り変化しておらず主に吸着していた水の脱離 によるものではないかと考兄られる99.

\section{2 加熱による重量変化}

Fig. 6 亿先の実験条件で加熱した際の Kaptonの重量 変化を示す。実験值は, 試料加熱時の重量減少をマイク 口天秤により測定した值で，また計算値は Fig. 5 に示 した各々の放出気体量を重量に換算し積算した值であ る. 重量減少は $450^{\circ} \mathrm{C} か ら 600^{\circ} \mathrm{C} て ゙$ 約 $10 \mu \mathrm{g}$ (全試料重量の $0.1 \%)$ で， $600^{\circ} \mathrm{C}$ 以上では急激に減少し $700^{\circ} \mathrm{C} て ゙ 40 \mu \mathrm{g}$ 減少していることがわかった。 また，計算値との比較で は全体的に実測值の方が約 2 から 3 倍大きくなってお り, これはFig. 2 で示した高分子量の気体の脱離が起 こっているためだと考兄られる，そこで，実測值と計算 値との差分をべンゼンとみなし，その脱離量を計算する と, $700^{\circ} \mathrm{C}, 5$ 時間の加熱で $1 \mathrm{~g}$ 当り約 $5 \times 10^{19}($ 分子 $/ \mathrm{g})$ が放出されたことになり，これはその時最も気体放出量 の多かった二酸化炭素の放出量の約 2 倍に相当するもの であった.

\section{3 加熱による構造変化}

Fig. 7 亿 Kaptonの加熱による構造変化を FT-IR で 測定した結果を示す. 試料は $700^{\circ} \mathrm{C}, 5$ 時間の加熱沙よっ てもはっきりとした差は認められなかったため， $800^{\circ} \mathrm{C}, 4$ 時間の加熱で $188 \mu \mathrm{g}$ （全試料重量の約 $2 \%$ )の 減少を示したものを用いた。 また，試料の赤外スペクト ルは透過法を用いて測定した.

Kapton の赤外吸収スペクトルでは，1720と $1780 \mathrm{~cm}^{-1}$ の複素 5 員環に結合しているカルボニル基の対称, 非対 称伸縮, 1500 と $1600 \mathrm{~cm}^{-1}$ のベンゼン環のブリージン グ, $1380 \mathrm{~cm}^{-1}$ の $\mathrm{C}-\mathrm{N}$ 伸縮, $1100 \sim 1300 \mathrm{~cm}^{-1}$ の $\mathrm{C}-\mathrm{O}$ 結合に属する吸收帯, 880 と $830 \mathrm{~cm}^{-1}$ の $\mathrm{C}-\mathrm{H}$ 伸縮等の
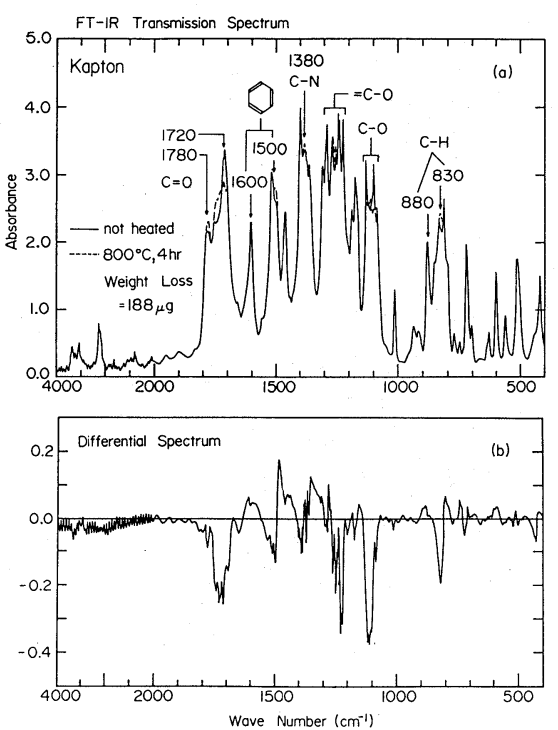

Fig. 7 Infrared Adsorption Spectra of Kapton. (a) Transmission Spectra and (b) Differential Spectrum before and after Heat Treatment at $800^{\circ} \mathrm{C}$ for $4 \mathrm{hr}$.

強い吸収ピークが観測された ${ }^{10)}$. 試料の加熱による変化 は, 差スペクトルより1700から1800 $\mathrm{cm}^{-1}$ にかけてのカ ルボニル基の吸収帯と $1100 か ら 1300 \mathrm{~cm}^{-1}$ にあるエーテ ル基の吸収帯, または $830 \mathrm{~cm}^{-1}$ の $\mathrm{C}-\mathrm{H}$ 結合の吸収ピー クが減少していることがわかった．この減少は, 加熱中 に $\mathrm{CO}$ や $\mathrm{CO}_{2}$ 等の気体が多く脱離するという結果と一 致している.

また，逆に $1480 や 1350 \mathrm{~cm}^{-1}$ 近傍に吸収の増大してい るピークも有り, これについてはっきりとした㷌属は分 かっていない、しかし, Kapton は真空中で $600^{\circ} \mathrm{Cから}$ $800^{\circ} \mathrm{C}$ の温度で加熱することにより炭素化の進行するこ とが知られており, 縮合環の形成によって生じたピーク ではないかと考えられる11).

\section{4. まとめ}

3 種類のポリイミド樹脂について真空中での加熱を行 い, 気体放出, 重量変化, 構造変化について調べた.

1）主な放出気体成分は, $\mathrm{H}_{2}, \mathrm{H}_{2} \mathrm{O}, \mathrm{CO}, \mathrm{CO}_{2}$ で, m/ $\mathrm{e}=50$ から100までの比較的高分子量の気体の放出もかな りあることが重量減少の結果からわかった.

2）気体放出量は $450 \sim 700^{\circ} \mathrm{C}, 5$ 時間の加熱で, Upilex $\mathrm{S}<$ Kapton < Upilex R の順となりガラス転移温度 から予想される結果と一致した。

3）加熱による Kapton の構造変化は $\mathrm{G}=\mathrm{O} （ 1720$ $\left.17810 \mathrm{~cm}^{-1}\right), \quad=\mathrm{C}-\mathrm{O}, \mathrm{C}-\mathrm{O} \quad\left(1100 \sim 1200 \mathrm{~cm}^{-1}\right), \mathrm{C}-\mathrm{H}$ 
$\left(830 \mathrm{~cm}^{-1}\right)$ の吸収ピーク強度が減少しており, 気体放 出で $\mathrm{CO}, \mathrm{CO}_{2}$ 等の酸素原子を含む気体が多く脱離する 結果と一致している.

\section{謝辞}

この研究に当たり, 試料を御提供して頂きました三菱 電機の園田克己氏に感謝いたします。

\section{[文献]}

1) P. W. Hait; Vacuum 17 (1967) 547

2）横倉賢治，花沢 稔; 真空， 24 (1981) 399

3）内田盛也；「先端複合材料」工業調査会（1986）
4）宇部興産「ユーピレックス」技術資料

5）ポリマーダイジェスト，11（1985） 3

6) K. NAKAYAMA et al; J. Nucl. Mater., 145 (1987) 301

7）中山喜明，福田 伸，山科俊郎 ; 真空，32（1989） 415

8) E. Stenhagan et al; Atlas of Mass Spectral Data (John Wiley and Sons, 1969)

9) 真空材料における放出量の試験評価法に関する調 査研究報告書（1987）20日本真空協会

10) C. A. PRYDE; J. Poly. Sci. A, Poly. Chem; 27 (1989) 711

11）神戸博太郎；「高分子の耐熱性」培風館（1975） 